\title{
Crystal structure and ionic conductivity of a new bismuth tungstate, $\mathrm{Bi}_{3} \mathbf{W}_{2} \mathbf{O}_{10.5}$
}

\author{
B MUKTHA and T N GURU ROW* \\ Solid State and Structural Chemistry Unit, Indian Institute of Science, Bangalore 560012 \\ e-mail: ssctng@sscu.iisc.ernet.in
}

\begin{abstract}
The compound $\mathrm{Bi}_{3} \mathrm{~W}_{2} \mathrm{O}_{10.5}$ was synthesized by the solid-state technique from $\mathrm{Bi}_{2} \mathrm{O}_{3}$ and $\mathrm{WO}_{3}$ in stoichiometric quantities. Single crystals were grown by the melt-cooling technique and the crystal structure was solved in the tetragonal $I 4 / m$ space group with $a=3.839$ (1) $\AA, c=16 \cdot 382$ (5) $\AA, V=241.4$ (1) $\AA^{3}, Z=4$ and was refined to an $R$ index of 0.0672 . The structure represents a modification of the Aurivillius phase and consists of $\left[\mathrm{Bi}_{2} \mathrm{O}_{2}\right]^{2+}$ units separated by $\mathrm{WO}_{8}$ polyhedra. a.c. impedance studies indicate oxide ion conductivity of $2.9110^{-5} \mathrm{Scm}^{-1}$ at $600^{\circ} \mathrm{C}$.
\end{abstract}

Keywords. Bismuth tungstate; single crystal X-ray diffraction; a.c. impedance; oxide ion conductivity.

\section{Introduction}

The discovery of Aurivillius phases ${ }^{1}$ has led to extensive studies on various bismuth-containing oxides for a wide range of applications. The family is represented by the general formula $\mathrm{Bi}_{2} \mathrm{M}_{n-1} \mathrm{R}_{n} \mathrm{O}_{3 n+3}$, where $\mathrm{M}=\mathrm{Bi}, \mathrm{Pb}, \mathrm{Nb}, \mathrm{K}, \mathrm{Sr}, \mathrm{Ca}, \mathrm{Ba}$ and rare earth ions, and $\mathrm{R}=\mathrm{Ti}, \mathrm{Nb}, \mathrm{Ta}, \mathrm{W}, \mathrm{Cr}$ and $\mathrm{V}$. The structure consists of $\mathrm{M}_{n-1} \mathrm{R}_{n} \mathrm{O}_{3 n+1}$ perovskite layers interleaved by sheets of $\left[\mathrm{Bi}_{2} \mathrm{O}_{2}\right]^{2+}$ units, where $n=1,2,3,4$ and 5 . The $\mathrm{Bi}_{2} \mathrm{O}_{3}-\mathrm{WO}_{3}$ system has been well investigated. Hey et $a l^{2}$ isolated two other bismuth tungstates, $\mathrm{Bi}_{2} \mathrm{WO}_{6}$ and $\mathrm{Bi}_{2} \mathrm{~W}_{2} \mathrm{O}_{9} . \mathrm{Bi}_{2} \mathrm{WO}_{6}{ }^{3}$ has a structure similar to that of the Aurivillius phases. The structure was described as a commensurate modulation of the Fmmm structure derived from an idealized parent $14 / \mathrm{mmm}$ structure. Electrical and optical properties of $\mathrm{Bi}_{2} \mathrm{WO}_{6}$ such as ferroelectricity, piezoelectricity, pyroelectricity and nonlinear dielectric susceptibility have been extensively studied. ${ }^{4}$

The structure of $\mathrm{Bi}_{2} \mathrm{~W}_{2} \mathrm{O}_{9}{ }^{5}$ presents an entirely different layered arrangement with $\left[\mathrm{Bi}_{2} \mathrm{O}_{2}\right]^{2+}$ sheets interleaved by $\mathrm{W}_{2} \mathrm{O}_{7}$ sheets of double octahedral layers thickness. Ling et $a l^{6}$ reported yet another modulated bismuth tungstate, $\mathrm{Bi}_{14} \mathrm{WO}_{24}$ with a structure related to that of fluorite type in the tetragonal $I 4 / \mathrm{m}$ space group. The structure was described to be a super structure of fluorite type $\delta-\mathrm{Bi}_{2} \mathrm{O}_{3}$. Crumpton et $\mathrm{Cl}^{7}$ reported the polymorphic modifications of

Dedicated to Prof J Gopalakrishnan on his 62nd birthday

*For correspondence
$\mathrm{Bi}_{14} \mathrm{WO}_{24}$. The low temperature monoclinic $C 2 / m$ phase is obtained by slow cooling of the high tetragonal temperature phase. A rotational disorder observed around the $c$ axis in the tetragonal $I 4 / \mathrm{m}$ form is reduced in the polymorphic $C 2 / \mathrm{m}$ form.

The $\mathrm{Bi}_{2} \mathrm{O}_{3}-\mathrm{WO}_{3}$ phase diagram appears to be fairly complicated. Solid solutions with very low content of $\mathrm{WO}_{3}$ exhibit $\beta-\mathrm{Bi}_{2} \mathrm{O}_{3}$ type structure. In the composition type, $\mathrm{Bi}_{2-x} \mathrm{~W}_{x} \mathrm{O}_{3+1 \cdot 5 x}$, three solid solution ranging from $0.064 \leq x \leq 0.134$ (type Ia), $0.134 \leq x \leq$ $0 \cdot 286$ (type Ib) and $0 \cdot 286 \leq x \leq 0 \cdot 364$ (type II) have been identified. ${ }^{8}$ Further, ionic properties of solid solution of the type, $\left(\mathrm{Bi}_{2} \mathrm{O}_{3}\right)_{1-\mathrm{x}}\left(\mathrm{WO}_{3}\right)_{x}^{9}(x=0.05-0 \cdot 5)$ indicate ionic conductivity of the order of $10^{-1} \mathrm{Scm}^{-1}$ at $880^{\circ} \mathrm{C}$ for $\left(\mathrm{Bi}_{2} \mathrm{O}_{3}\right)_{0.78}\left(\mathrm{WO}_{3}\right)_{0.22}$. We are interested in the structural features of novel phases in the $\mathrm{Bi}_{2} \mathrm{O}_{3}-\mathrm{WO}_{3}$ system, in particular to generate new structural types.

In this context we have synthesized $\mathrm{Bi}_{3} \mathrm{~W}_{2} \mathrm{O}_{10.5}$ by the solid-state technique and in this article we report the single crystal $\mathrm{X}$-ray structure and preliminary studies on a.c. impedance of the compound.

\section{Experimental section}

\subsection{Preparation}

$\mathrm{Bi}_{2} \mathrm{O}_{3}$ (Fluka, 99.99\%) was dried at $600^{\circ} \mathrm{C}$ before use and $\mathrm{WO}_{3}$ (Fluka, 99.99\%) was used as such. A polycrystalline sample of $\mathrm{Bi}_{3} \mathrm{~W}_{2} \mathrm{O}_{10.5}$ was synthesized by the solid-state method using $\mathrm{Bi}_{2} \mathrm{O}_{3}$ and $\mathrm{WO}_{3}$ in stoichiometric quantities. The starting materials 
were ground well in an agate mortar and fired at $850^{\circ} \mathrm{C}$ for $24 \mathrm{~h}$ in a platinum crucible. Preliminary powder X-ray patterns confirm the formation of a single phase. Single crystals of $\mathrm{Bi}_{3} \mathrm{~W}_{2} \mathrm{O}_{10.5}$ were obtained by melting the polycrystalline sample at $1000^{\circ} \mathrm{C}$ and slow cooled at the rate of $1{ }^{\circ} \mathrm{C} / \mathrm{min}$ up to $935^{\circ} \mathrm{C}$ and then furnace-cooled to room temperature to yield transparent, pale yellow single crystals of $\mathrm{Bi}_{3} \mathrm{~W}_{2} \mathrm{O}_{10.5}$. Powder pattern of a crushed sample of single crystals was recorded to confirm the purity of the phase of the single crystals.

\subsection{Characterization}

2.2a Single crystal $X$-ray diffraction: Single crystal X-ray diffraction data were collected on a Bruker Axs SMART APEX CCD diffractometer ${ }^{10}$ with a crystal to detector distance of $6.06 \mathrm{~cm}$. The data were collected based on 3 sets of runs covering a complete sphere of reciprocal space with each set at different $\varphi$ angles $\left(\varphi=0,90,180^{\circ}\right)$. Each frame covered $0 \cdot 3$ degrees in $\omega$. The data were reduced using SAINT PLUS ${ }^{11}$ and the structure was solved by direct methods using SHELXS97 and refined using SHELXL97. ${ }^{12}$ Crystallographic data and the details of the single crystal data collection are given in table 1.

Table 1. Crystallographic data for $\mathrm{Bi}_{3} \mathrm{~W}_{2} \mathrm{O}_{10.5}$.

\begin{tabular}{ll}
\hline Crystal data & \\
\hline Empirical formula & $\mathrm{Bi}_{3} \mathrm{~W}_{2} \mathrm{O}_{10.5}$ \\
Crystal habit, colour & Cylindrical, yellow \\
Crystal size & $0 \cdot 086 \times 0 \cdot 131 \times 0 \cdot 248$ \\
Crystal system & Tetragonal \\
Space group & $I 4 / m$ \\
Cell dimensions $\left(\AA /{ }^{\circ}\right) a=$ & $3 \cdot 839(1)$ \\
& $16 \cdot 382(5)$ \\
Volume $\left(\AA^{3}\right) \quad b=$ & $241 \cdot 4(1)$ \\
Formula weight & $1162 \cdot 64$ \\
Density $($ calculated $)\left(\mathrm{g} / \mathrm{cm}^{3}\right)$ & $7 \cdot 997$ \\
$Z$ & 4 \\
$F(000)$ & 481 \\
Scan mode & $\omega$ scan \\
$\theta$ range $($ deg $)$ & $2 \cdot 49-25 \cdot 91$ \\
Recording reciprocal space & $-4 \leq h \leq 4,-4 \leq k \leq 4$, \\
& $-20 \leq l \leq 20$ \\
Number of measured & 875 \\
$\quad$ reflections & $134[R($ int $)=0 \cdot 0243]$ \\
Number of independent & \\
reflections & $78 \cdot 267$ \\
$\mu($ mm & -1 \\
Number of refined parameters & 9 \\
$R[I>4 \sigma I] / R[$ all data & $0 \cdot 0692 / 0 \cdot 0692$ \\
$W R[I>4 \sigma I] / R[$ all data $]$ & $0 \cdot 1841 / 0 \cdot 1841$ \\
GoF & $1 \cdot 088$ \\
Max/min $\Delta \rho e / \AA^{3}$ & $5 \cdot 481 /-3 \cdot 293$ \\
\hline
\end{tabular}

2.2b a.c. Impedance: A circular pellet of $\mathrm{Bi}_{3} \mathrm{~W}_{2} \mathrm{O}_{10.5}$ of about $10 \mathrm{~mm}$ diameter was sintered at $700^{\circ} \mathrm{C}$. The sintered sample was sputtered with gold. The sample was then mounted in an impedance jig and placed in a tube furnace where the temperature was controlled to $\pm 3^{\circ} \mathrm{C}$ over the range $30-600^{\circ} \mathrm{C}$. a.c Impedance measurements were carried out between $5 \mathrm{~Hz}$ and $13 \mathrm{MHz}$ on a Hewlett-Packard HP4192A impedance gain phase analyzer. A home built cell assembly with a 2-terminal capacitor configuration and stainless steel electrodes were used for the experiment. The sample temperature was measured using a $\mathrm{Pt}-\mathrm{Rh}$ thermocouple positioned very close to the sample. The frequency dependence of the impedance was measured between $30^{\circ}$ and $600^{\circ} \mathrm{C}$ in a heating-cooling cycle. The samples were equilibrated for half an hour at every temperature. The ionic conductivity was calculated from the intercept of the single semicircular arcs obtained in the complex impedance plots.

\section{Results and discussion}

\subsection{Crystal structure}

The yellow compound, $\mathrm{Bi}_{3} \mathrm{~W}_{2} \mathrm{O}_{105}$ crystallized into the tetragonal $I 4 / m$ system with $a=3.839$ (1) $\AA$, $c=16.382(5) \AA, V=241.4(1) \AA^{3}$ and $Z=4$. Table 1 lists the crystallographic details. The positions of the $\mathrm{Bi}$ and $\mathrm{W}$ atoms were obtained by direct methods and all the remaining oxygen atoms in the structure were located by difference Fourier synthesis. Initial isotropic thermal parameters indicate that the occupancy of the bismuth atom at the $4 e$ site needs to be re-refined. On refining the occupancy and isotropic thermal parameter of the $\operatorname{Bi}(1)$ atom alternately, the occupancy factor converged to a value of $\mathrm{Bi}(1)$ was located at the $4 e$ site with a large thermal parameter. So the occupancy of $\mathrm{Bi}(1)$ was refined with fixed isotropic thermal factor. The refinements converged for an occupancy factor of 0.187(2). This amounts to $75 \%$ occupancy at the $4 e$ site by the $\mathrm{Bi}(1)$ atom resulting in $3 \mathrm{Bi}$ atoms in the unit cell. The oxygen atoms located by the difference Fourier also revealed large thermal parameters with $\mathrm{O}(1)$ and $\mathrm{O}(2)$ occupying the $4 d$ and $8 g$ sites respectively. In order to balance the stoichiometry and also investigate the high thermal parameters of oxygen atoms, the occupancy of oxygen atoms were also refined in the same way as that of $\mathrm{Bi}(1)$ atom. The final cycles of refinement converge to an $R=0.0692$ with $\mathrm{O}(1)$ 
Table 2. Fractional atomic co-ordinates and equivalent thermal parameters $\left(U_{\text {eq }}\right)$ for $\mathrm{Bi}_{3} \mathrm{~W}_{2} \mathrm{O}_{10.5}$.

\begin{tabular}{lcccccc}
\hline Atom & $x$ & $y$ & $z$ & Occupancy & Wykcoff position & $U(\mathrm{eq}) \AA^{2}$ \\
\hline Bi1 & $-0 \cdot 5$ & $-0 \cdot 5$ & $-0 \cdot 16763(18)$ & $0 \cdot 75$ & $4 e$ & $0 \cdot 0404(12)$ \\
W1 & 0 & 0 & 0 & 1 & $2 a$ & $0 \cdot 0165(11)$ \\
O1 & $-0 \cdot 5$ & $-1 \cdot 0$ & $-0 \cdot 25$ & 1 & $4 d$ & $0 \cdot 11(5)$ \\
O2 & 0 & $-0 \cdot 5$ & $0 \cdot 068(3)$ & $0 \cdot 81$ & $8 g$ & $0 \cdot 10(2)$ \\
\hline
\end{tabular}

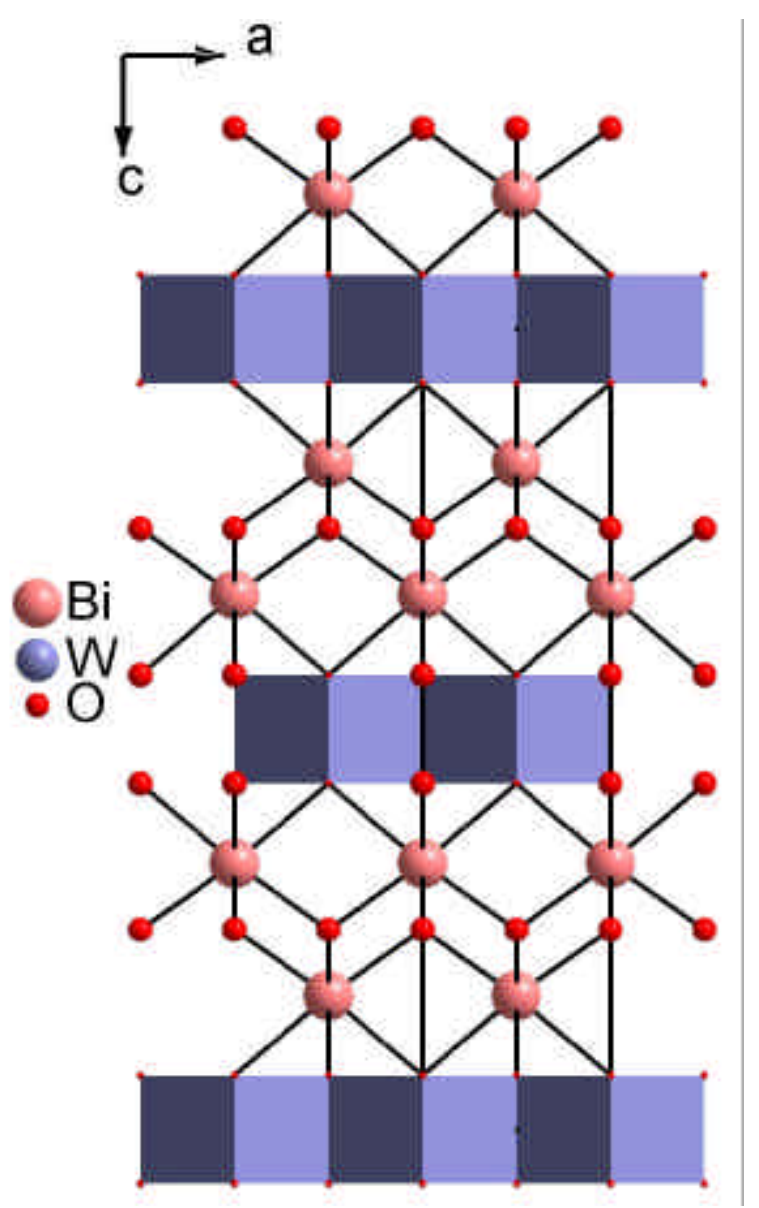

Figure 1. Crystal structure of $\mathrm{Bi}_{3} \mathrm{~W}_{2} \mathrm{O}_{10.5}$ along the $b$ axis.
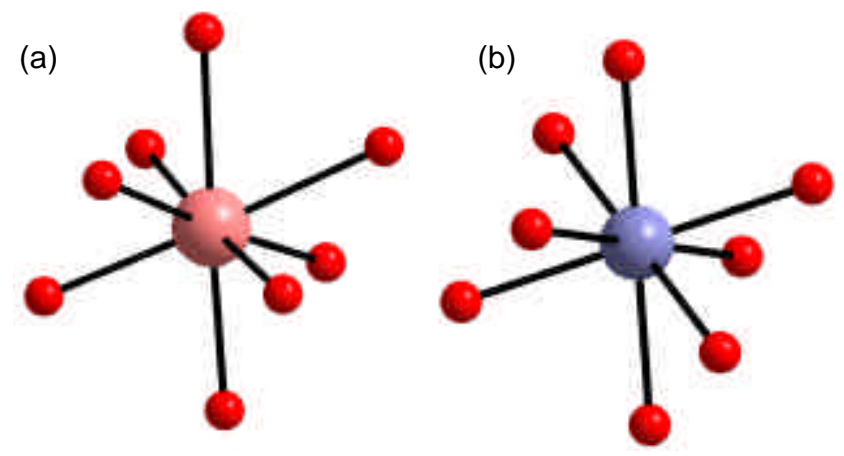

Figure 2. Co-ordination around (a) $\mathrm{Bi}$ and (b) $\mathrm{W}$ atoms. fully occupied at the $4 d$ site and $\mathrm{O}(2)$ at the $8 g$ site with an occupancy of 0.40 (2). Hence the final stoichiometry is $\mathrm{Bi}_{3} \mathrm{~W}_{2} \mathrm{O}_{10.5}$. The fractional atomic co-ordinates for all the atoms are listed in table 2.

The crystal structure of $\mathrm{Bi}_{3} \mathrm{~W}_{2} \mathrm{O}_{10.5}$ along the $b$ axis is shown in figure 1 . Layers of $\left[\mathrm{Bi}_{2} \mathrm{O}_{2}\right]^{2+}$ units are interlinked by $\mathrm{WO}_{8}$ polyhedra with $\mathrm{Bi}(1)$ atom surrounded by eight oxygen atoms resulting in a $\mathrm{BiO}_{8}$ polyhedra. The $\mathrm{BiO}_{8}$ polyhedra is formed by linking $\mathrm{Bi}(1)$ to four each of symmetrically related $\mathrm{O}(1)$ and $\mathrm{O}(2)$ atoms. The $\mathrm{Bi}(1)-\mathrm{O}(1)$ and $\mathrm{Bi}(1)-\mathrm{O}(2)$ distances are 2.346 (1) $\AA$ and 2.52 (4) $\AA$ respectively. The coordination of $\mathrm{Bi}(1)$ and $\mathrm{W}(1)$ atoms are shown in figure 2 . $\mathrm{Bi}(1)$ is connected to $\mathrm{W}(1)$ by edge sharing of $\mathrm{O}(2)$ atoms through the long $\mathrm{Bi}(1)-\mathrm{O}(2)$ contacts. $\mathrm{W}(1)$ is connected to symmetrically related $\mathrm{O} 2$ atoms at distances 2.22 (3) Å. Further, the $\mathrm{WO}_{8}$ polyhedra are linked to one another by edge sharing along the $a$ and $c$ axes.

The main structural difference between $\mathrm{Bi}_{3} \mathrm{~W}_{2} \mathrm{O}_{10.5}$ and the Aurivillius phase lies in the fact that the layers of $\left[\mathrm{Bi}_{2} \mathrm{O}_{2}\right]^{2+}$ units are connected to the $\mathrm{WO}_{8}$ polyhedra by edge sharing whereas in the Aurivillius phases the layers of $\left[\mathrm{Bi}_{2} \mathrm{O}_{2}\right]^{2+}$ units occur separately. This is the first example of an eight co-ordinated $\mathrm{W}$ atom in a bismuth tungstate.

\section{2 a.c. impedance}

a. c. Impedance studies suggest a conductivity value of $2.91 \times 10^{-5} \mathrm{Scm}^{-1}$ at $600^{\circ} \mathrm{C}$. The X-ray powder pattern of the sample indicates no change after the conductivity measurements. The heating and the cooling cycles show no changes in the Arrhenius plot. The reported results correspond to the heating cycle. Figure 3 shows the Arrhenius plot of conductivity. The variation of $\log \sigma$ with $1 / T$ indicates linear behaviour, thus indicating the absence of any phase transition. This feature is further confirmed by DTA data recorded up to $700^{\circ} \mathrm{C}$, which shows no phase transition in the whole range. The moderate conductivity is via oxygen ions. 


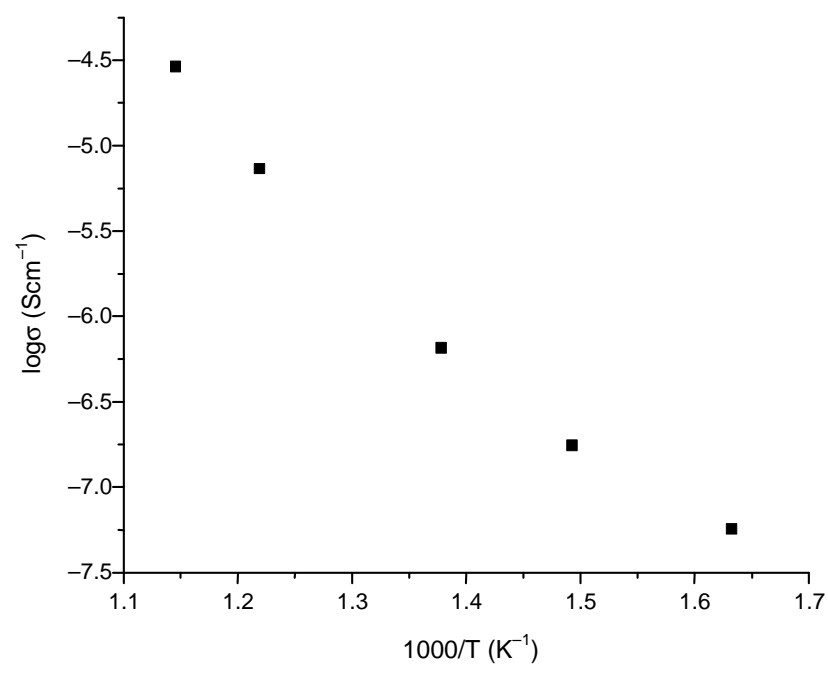

Figure 3. Conductivity Arrhenius plot of $\mathrm{Bi}_{3} \mathrm{~W}_{2} \mathrm{O}_{10 \cdot 5}$.

\section{Summary}

A new bismuth tungstate, $\mathrm{Bi}_{3} \mathrm{~W}_{2} \mathrm{O}_{10.5}$ was synthesized and characterized by single-crystal $\mathrm{X}$-ray diffraction. The structure shows deviation from an ideal Aurivillius phase in terms of the arrangement of $\mathrm{Bi}$ and $\mathrm{W}$ atoms. Unlike in the regular Aurivillius phases, where $\mathrm{W}$ atom is octahedrally co-ordinated, $\mathrm{Bi}_{3} \mathrm{~W}_{2} \mathrm{O}_{10.5}$ depicts an unusual co-ordination for $\mathrm{W}$ atom and is linked to eight oxygen atoms at equal distances. The ionic conductivity of the order of $10^{-5} \mathrm{Scm}^{-1}$ indicates moderate oxygen ion conductivity.

\section{Acknowledgement}

Single-crystal X-ray data collection was done on the CCD facility under the IRPHA-DST program, De- partment of Science and Technology, New Delhi. BM thanks Council of Scientific and Industrial Research, New Delhi for a fellowship.

\section{Supporting information available}

CIF crystal data have been deposited at the Fachinformationszentrum Karlsruhe (FIZ) with the number CSD 415848.

\section{References}

1. Aurivillius B 1950 Ark. Kemi. 219

2. Hey M H, Bannister M A and Russell A 1938 Miner. Mag. 2541

3. Rae A D, Thompson J G and Withers R L 1991 Acta Crystallogr. B47 870

4. Newkirk H W, Quadflieg P, Liebertz J and Kockel A 1972 Ferroelectrics 4 51; Stefanovich S Yu and Venetsev N Yu 1973 Phys. Status Solidi A20 K49; Ismailzade I G and Mirishli F A 1970 Kristallografiya 14 738; Yanovskii V K, Voronkova V I, Alexandrovskii A L and D'yakov V A 1975 Dokl. Akad. Nauk SSSR 222 94; Utkin V I, Roginskaya Yu E, Voronkova V I, Yanovskii V K, Galyamov B Sh and Venetsev Yu N 1980 Phys. Status Solidi A59 75

5. Champarnaud-Mesjard J C, Frit B and Watanabe A 1999 J. Mater. Chem. 91319

6. Ling C D, Withers R L, Thompson J G and Schmis S 1999 Acta Crystallogr. B55 306

7. Crumpton T E, Francesconi M G and Greaves C 2003 J. Solid State Chem. 175197

8. Zhou W 1994 J. Solid State Chem. 108381

9. Takahashi T and Iwahara H 1973 J. Appl. Electrochem. 365

10. Bruker 2000 SMART (Version 5.625), SAINT (Version 6.45a) RLATT (Version 3.0). Bruker AXS Inc, Madison, WI, USA

11. Sheldrick G M 1997 SHELXL97. Program for crystal structure refinement. University of Göttingen, Germany 